\title{
BRAND SYMMETRY INDEX MODEL TO \\ MEASURE BRAND UNIQUENESS
}

${ }^{1}$ Mr. Manoj Pandey, 'Dr. J. K. Raju, B.E., MBA, PhD

\begin{abstract}
In the marketplace, differentiation is the key. Any marketer - be it a producer, intermediary, seller or an agent - consistently tries to offer something different than what is being offered in the market. Even generic products and services such as salt, wheat, rice, hair salons, and telecom services tries to woo customers with their differentiation messages. Many researchers have emphasized the need to differentiate the brand, however very few models exist to measure it. The present research is focused on developing a tool which can be used to measure brand differentiation through a concept called 'Brand Symmetry Index'. The idea is to investigate brand attributes which are closely associated with its success and then perform various multivariate interdependent analyses to study the relationship between them.
\end{abstract}

Keywords: Brand Perception, Brand Attributes, Brand Uniqueness, Brand Symmetry

\section{INTRODUCTION}

Brand is one of the most valuable intangible assets of any organization. Hence it is imperative to manage it well to maximize its returns. The end-result of creating a successful brand fundamentally rests with the customers. Organizations can do their best to create a successful brand, but the question is whether customer also perceives the same about the brand. The marketing activity linked with the brand tries to influence the customer's mind towards the brand. This creates a customer disposition and behaviour towards the brand (McAllister and John, Dec 2004). The customer then starts relating the brand with his environment.
Perceived Brand Symmetry is the aggregate perception a customer holds about the brand's differentiation in a product category. At higher brand symmetry, the brand differentiation in a product category would be low. On the other hand, if the customer perceives major differences between the brands in a product category, then the brand symmetry is low. Consumer good firms today are facing the biggest challenge of falling into high brand symmetry zone. This could lead to huge loss in brand equity. The classic case is of Marlboro in 1993. Philip Morris acknowledged that market share of Marlboro was going down and newer brands were emerging as market winners which many had not even heard of. The reason cited was 'Marlboro was not able to distinguish

\begin{tabular}{lll}
$\begin{array}{l}\text { Mr. Manoj Pandey } \\
\text { PhD Research Scholar } \\
\text { Kuvempu University, P.G Center } \\
\text { Davangere, Karnataka }\end{array}$ & $\begin{array}{l}\text { Dr. J. K. Raju, B.E., MBA, PhD } \\
\text { Associate Professor } \\
\text { Institute of Management Studies } \\
\text { Kuvempu University, P.G Center } \\
\text { Davangere, Karnataka }\end{array}$ \\
\hline
\end{tabular}


enough in consumers mind'. In April 1993, the market reacted extremely and about $\$ 13.5$ billion was wiped out from market capitalization of Philip Morris. The market thought that if this can happen to Marlboro, other brands can also fall to brand symmetry. As fear grew, this led to a chain reaction with share prices of Proctor \& Gamble, Coca-cola, Gillette, and PepsiCo came down tumbling (Economist 1993).

Advertising has a very important role to play in creating concepts such as 'brand uniqueness'. Rosser Reeves in 1961 wrote a book on advertising ('Reality in Advertising') which was considered to be the textbook on advertising during those days. He believed that the purpose of advertising is to sell. He insisted that an advertisement or commercial should show off the value of a product, not the cleverness of a copywriter. His most typical ad is probably that for Anacin, a headache medicine. The ad was considered grating and annoying by almost all viewers but it was remarkably successful, tripling the product's sales. In 7 years, the 59second commercial made more money than the movie Gone with the Wind had in a quartercentury. His ads were focused around what he called the Unique Selling Proposition, the one reason the product needed to be bought or was better than its competitors. Kanter (1981) and Stellt (1977) also supported the idea that the purpose of advertising is to counter brand symmetry. Due to two reasons, brand managers fear from brand symmetry:

1. It is believed that in case of high brand symmetry, consumers will start looking at the next most important attribute in a brand (which is price). Consumer could become more price sensitive, forcing the brand to encounter price elasticity. To survive, the brand price needs to be reduced, hitting its margin and profitability.

2. It is also believed that brand loyalty is inversely linked with brand symmetry. High brand loyalty gets translated into higher brand equity which is generally difficult to create when brand symmetry perceptions are high in the market. Since brand symmetry impacts brand profitability in long run, it is imperative to manage it well.

The importance of brand uniqueness is further advocated by Aaker (1996). He advises brand strategists to consider the brand as a product, an organization, a person and a symbol. The purpose of this system is to help brand strategists consider different brand elements and patterns that can help clarify, enrich and differentiate an identity. Kevin (2005) advises to focuses on the use of effective advertising to create an equity position in the marketplace. The author says that effective advertising can be a powerful part of a company's marketing plan, and it is an important investment in the company. When done correctly, the company can generate between $10 \%$ and $30 \%$ more growth than a similarly sized competitor that does not advertise. Rajesh and James (2005) further investigated the relationship between brand loyalty and brand uniqueness. They recommend using advertising to fight brand similarity.

Considering the above discussion, it is imperative that the brand managers should have a practical tool to measure their brand differentiation score in comparison to their competitor brands. If the brand is not able to distinguish itself in the marketplace than the marketing communication strategy is probability not effective. This needs to be 
investigated. Considering that in mind, the research is focused on developing a brand symmetry index model.

\section{BRAND SYMMETRY INDEX (BSI) CONCEPT}

Brand Symmetry Index is a score indicating the level of brand uniqueness as perceived by the customer in that product / service category. The score ranges from $0-100$. Low score indicates that the brand is uniquely positioned. Higher score on the other hand indicates that the brand has not been able to position itself uniquely and there is high similarity with competitor brands.

It is proposed to take one product category (Oral Care) and one service category (Life Insurance) brands and compute their Brand Symmetry Index Scores.

\section{BSI Computation}

The BSI computation is based on logistic regression. 'Unique' is the target variable with other attributes being taken as independent variables.
Three sets of logistic regression will be run as discussed below:

Logistic Regression on Attribute 'Unique' with no weights on other attributes

Logistic Regression on Attribute 'Unique' with linear weight on Attribute 'Familiarity'

Logistic Regression on Attribute 'Unique' with exponential weight on Attribute 'Familiarity'

The outcome of logistic regression will be converted into a BSI score using the probability algorithm as shown below:

Log odds $=c+b 1 * \times 1+b 2 * \times 2+\ldots$

Log odds $=\mathrm{c}+\mathrm{b} 1 *$ (mean of $x 1$ for that brand $)+$ $b 2 *$ (mean of $x 2$ for that brand) $+\ldots$

Convert Log odds into probability using $[P=1 /$ $\left(1+e^{\wedge}-f(x)\right]$

Brand Symmetry Index $=100 *$ (1- Probability)

The summary of the modeling process is outlined in the figure below.

Figure 1: BSI Modeling Process

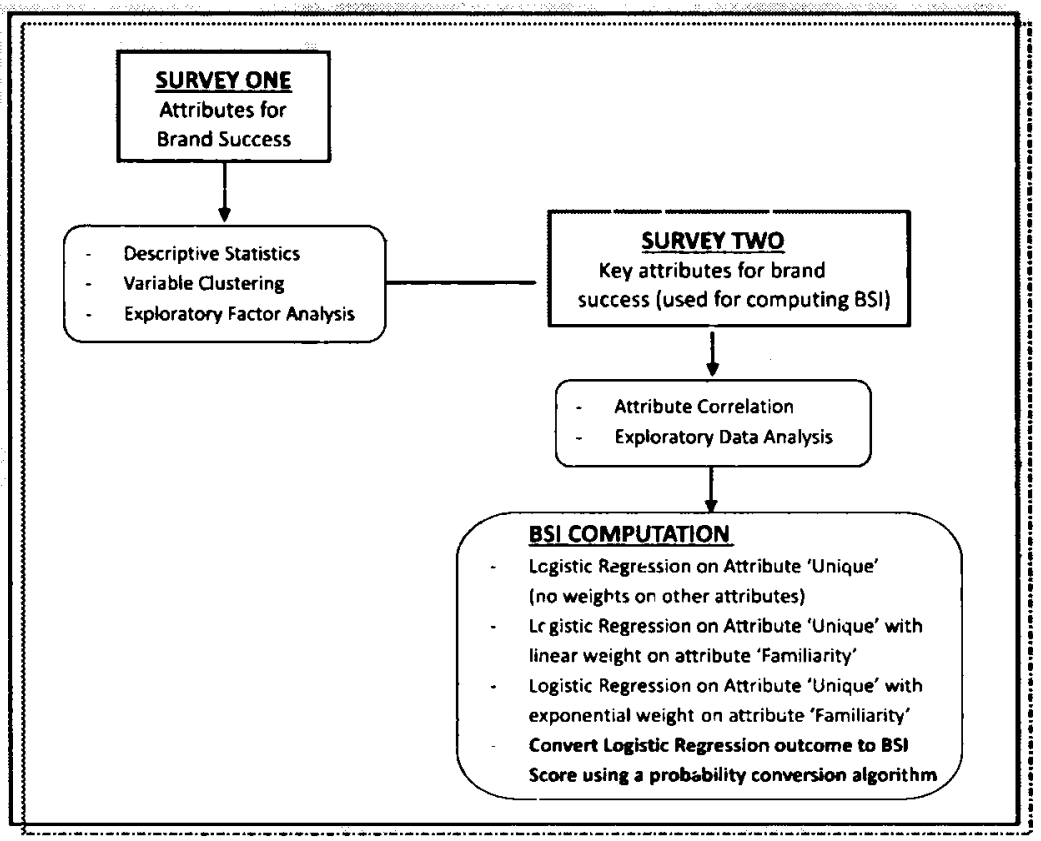


The research is conducted in two phases:

The first survey was conducted to study which brand attributes are more important in determining brand success. The idea is to group similar brand attributes together and converge on a list of smaller number of attributes for second survey. The sample size was 200 (academicians at management colleges).

The second survey was conducted to study the brand success across two sectors. The selected variables from survey one was used for survey two. The sample size was 500 consumers comprising of students/employed people/ housewives/businessmen.

\section{SCOPE OF THE STUDY}

The scope is limited to the following two sectors: Life Insurance and Oral Care (one each from Product and Service). Brands limited to the following:

Table 1: Sector, Brand Code and Brand Name

\begin{tabular}{|l|c|l|}
\hline Sector & Brand Code & Brand Name \\
\hline Life Insurance & 1 & LIC \\
\hline Life Insurance & 2 & ICICI Prudential \\
\hline Life Insurance & 3 & SBI Life \\
\hline Life Insurance & 4 & HDFC Standard Life \\
\hline Life Insurance & 5 & Bajaj Allianz \\
\hline Life Insurance & 6 & Birla Sunlife \\
\hline Life Insurance & 7 & Max New York Life \\
\hline Oral Care & 1 & Colgate \\
\hline Oral Care & 2 & Close-up \\
\hline Oral Care & 3 & Pepsodent \\
\hline Oral Care & 4 & Dabur Red \\
\hline Oral Care & 5 & Vicco \\
\hline Oral Care & 6 & Cibaca \\
\hline
\end{tabular}

Survey Area: Bangalore city (being cosmopolitan, generalization of research results would be easier across segments and markets). The intent of the study is to develop the BSI model and validate the algorithm/ modeling process. The BSI score computed for a brand is at one point in time and replicating the study may not give the same score again.

\section{LIMITATIONS OF THE STUDY}

It is important to mention that the scope of this study only focused on investigating the relationship between customer attributes and brand symmetry (though a very important one). The study is limited to the symmetry perception of sampled customers only. The research however does not reject other possible links between specific attributes or combination of attributes and customer behaviour. For example:

- Customers may give higher priority to some attributes than others in deciding their choice and response.

Particular brand positioning may be more valuable for acquiring new customers and hence the customer response being influenced by it.

The above areas of research would definitely be 
of good value. Apart from this, it can also happen that the attribute importance for a customer can alter the effect on brand loyalty or brand symmetry. Though at aggregate level, the effect appears to neutralize each other. Considering this, looks like attribute importance is not very significant at aggregate level. However attribute importance may have some vital inferences at the customer level, hence the need to carry out further investigation.

For generalization of the research, it is recommended to replicate and extend the model across a broad range of products and markets (including urban and rural) especially in the area of Consumer Packaged Goods (CPG).
This is important considering the paper 'The measurement \& dimensionality of brand associations' by Lamb and Low (2000) in which it is argued that level of brand knowledge and experience may contribute to deviation in results across different product categories.

\section{DATA ANALYSIS}

\section{A. Survey One}

Clustering technique was used to select the key variables for Brand Success. Maximum Cluster Criteria used for this technique is 7 (MAXCLUSTER = 7). SAS output and summary for the Centroid Method is below.

Figure 2: Variable Cluster - SAS output for the Centroid Method

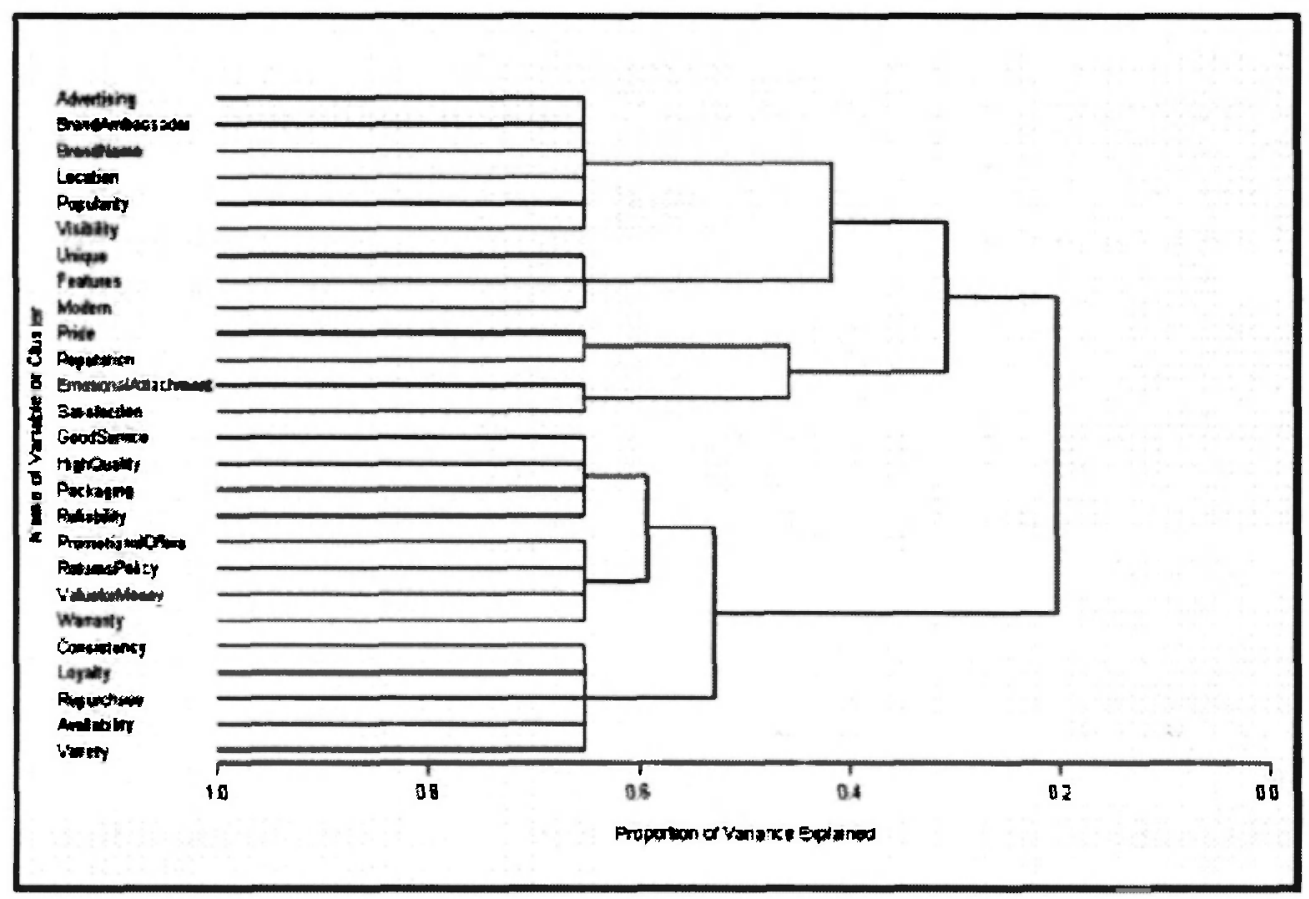

SAS procedure 'PROC VARCLUS' with Centroid method produced seven variable segments which explained $65.2 \%$ of the variation. The seven variable segments were again validated by using Exploratory Factor Analysis (EFA), refer
Table 2. Highlighted in green are the association between Factors and Attributes. For example Advertising is associated with Factor 1 (highest factor loading of 0.74 ). 
Table 2: EFA - Rotated Factor Pattern (Standardized Regression Coefficients)

\begin{tabular}{|c|c|c|c|c|c|c|c|}
\hline \multirow[b]{2}{*}{ Brand Attributes } & \multicolumn{7}{|c|}{ Factors } \\
\hline & Factor1 & Factor? & Factor3 & Factor4 & Factors & Factor6 & Factor7 \\
\hline Advertising & 0.74 & -0.01 & -0.01 & 0.03 & 0.02 & -0.02 & 0.16 \\
\hline BrandAmbassader & 0.71 & 0.15 & -0.14 & -0.15 & -0.09 & -0.05 & 0.12 \\
\hline Unique & 0.25 & -0.06 & 0.05 & 0.01 & -0.16 & -0.11 & 0.25 \\
\hline BrandName & 0.53 & -0.07 & 0.07 & 0.14 & 0.06 & -0.13 & -0.11 \\
\hline Features & 0.38 & -0.16 & -0.09 & 0.16 & 0.13 & 0.03 & 0.43 \\
\hline EmotionalAttachment & -0.05 & 0.00 & -0.01 & -0.02 & 0.00 & 0.85 & 0.03 \\
\hline Consistency & -0.02 & 0.84 & 0.02 & -0.01 & 0.03 & -0.07 & -0.06 \\
\hline GoodService & 0.04 & 0.07 & 0.77 & 0.00 & 0.01 & -0.09 & -0.08 \\
\hline HighQuality & 0.05 & 0.07 & 0.87 & -0.08 & -0.01 & -0.05 & -0.04 \\
\hline Location & 0.50 & 0.24 & -0.08 & -0.10 & -0.05 & 0.00 & -0.07 \\
\hline Loyalty & -0.03 & 0.61 & 0.09 & -0.07 & -0.05 & 0.01 & 0.46 \\
\hline Modern & 0.53 & -0.11 & 0.29 & -0.11 & -0.03 & 0.07 & 0.11 \\
\hline Packaging & -0.06 & -0.07 & 0.54 & 0.10 & 0.00 & 0.01 & 0.10 \\
\hline Popularity & 0.72 & 0.03 & 0.03 & 0.07 & 0.00 & 0.03 & 0.23 \\
\hline Pride & 0.02 & 0.00 & -0.04 & -0.02 & 0.87 & 0.00 & -0.01 \\
\hline PromotionalOffers & 0.04 & 0.04 & 0.05 & 0.71 & -0.04 & -0.10 & -0.01 \\
\hline Reliability & 0.00 & 0.05 & 0.69 & 0.17 & 0.02 & 0.12 & 0.01 \\
\hline Repurchase & -0.09 & 0.53 & 0.12 & -0.02 & -0.01 & 0.00 & $0 . \overline{51}$ \\
\hline Reputation & -0.02 & 0.05 & 0.05 & -0.08 & 0.88 & -0.03 & 0.07 \\
\hline ReturnsPolicy & -0.05 & -0.05 & 0.12 & 0.74 & 0.05 & -0.02 & 0.14 \\
\hline Satisfaction & 0.06 & 0.01 & 0.01 & -0.03 & -0.02 & 0.86 & -0.04 \\
\hline Availability & 0.08 & 0.83 & -0.02 & 0.10 & 0.09 & 0.00 & -0.03 \\
\hline ValueforMoney & -0.04 & 0.25 & -0.14 & 0.83 & -0.03 & 0.04 & 0.06 \\
\hline Variety & 0.12 & 0.70 & 0.00 & 0.10 & -0.02 & 0.08 & -0.09 \\
\hline Visibility & 0.41 & 0.01 & 0.12 & 0.11 & 0.06 & 0.15 & -0.15 \\
\hline Warranty & 0.02 & -0.05 & 0.13 & 0.52 & -0.13 & 0.00 & -0.05 \\
\hline
\end{tabular}


The factor loading are displayed in the Figure 3 below:

Figure 3: FFA - Factor Loading

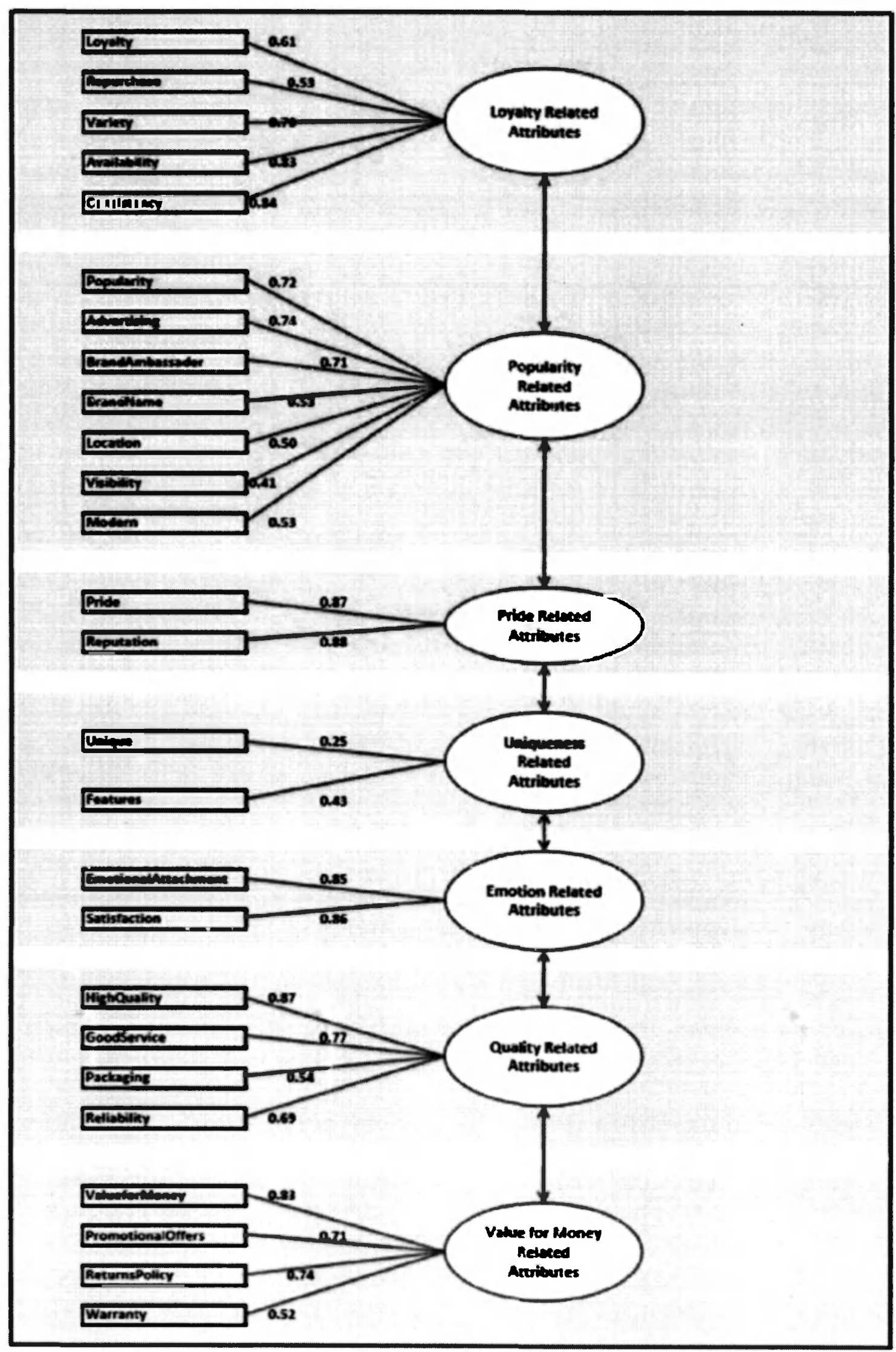


The factors are weakly correlated with each other (correlation coefficient $<0.5$ ). This indicates that the factors are independently responsible for the item distribution they represent. It also denotes absence of multicollinearity.

Final set of variables taken for Survey Two are:

- Popularity

- Loyalty

- High Quality

- Value for Money

- Pride

- Emotional Attachment

- Unique

- Familiarity - This variable has been added to incorporate the consumer's knowledge about the brand and its features to further enhance the response. It will be used as a Blocking Factor while computing Brand Symmetry Index Score

\section{A. Survey Two}

BSI at brand level was computed by taking the brand level mean of attribute - Unique. Any record with Unique attribute value greater than brand mean was converted as 1 else 0 thus creating a UniqueFlag variable. UniqueFlag variable was then set as target variable in logistic regression and other variables were used as independent variable.

Three variants of logistic regression were run:

- No Weight: Simple Logistic Regression Target Variable: UniqueFlag Independent Variables: Familiarity, VFM, Popularity, Pride, HighQuality (HQ), Loyalty and Emotion

- Linear Weight: Linear Weight on Familiarity given by $[1+$ (familarity/avg familiarity)]

Target Variable: UniqueFlag Independent Variables: VFM, Popularity, Pride, HighQuality $(\mathrm{HQ})$, Loyalty and Emotion

- Exponential Weight: Exponential Weight on Familiarity given by [exp (familiarity)] Target Variable: UniqueFlag Independent Variables: VFM, Popularity, Pride, HighQuality $(\mathrm{HQ})$, Loyalty and Emotion

The summary of outputs is below.

\section{Insurance Sector Brands}

Table 3: Brand Level BSI for Insurance Sector - Percentage Concordant and C Value

\begin{tabular}{|c|c|c|c|c|c|c|}
\hline Brand & \multicolumn{2}{|c|}{ Percentage Concordant } & \multicolumn{3}{c|}{ C value } \\
\hline & $\begin{array}{c}\text { No } \\
\text { Weight }\end{array}$ & $\begin{array}{c}\text { Linear } \\
\text { Weight }\end{array}$ & $\begin{array}{c}\text { Expo } \\
\text { Weight }\end{array}$ & $\begin{array}{c}\text { No } \\
\text { Weight }\end{array}$ & $\begin{array}{c}\text { Linear } \\
\text { Weight }\end{array}$ & $\begin{array}{c}\text { Expo } \\
\text { Weight }\end{array}$ \\
\hline 1 & 65.1 & 64.9 & 64.8 & 0.653 & 0.651 & 0.651 \\
\hline 2 & 71.9 & 71.1 & 71.0 & 0.721 & 0.712 & 0.711 \\
\hline 3 & 71.6 & 70.8 & 70.9 & 0.718 & 0.710 & 0.710 \\
\hline 4 & 66.9 & 67.0 & 66.8 & 0.672 & 0.672 & 0.671 \\
\hline 5 & 69.8 & 69.7 & 68.8 & 0.700 & 0.698 & 0.689 \\
\hline 6 & 68.5 & 66.2 & 65.9 & 0.687 & 0.665 & 0.661 \\
\hline 7 & 59.9 & 59.9 & 59.6 & 0.602 & 0.602 & 0.599 \\
\hline
\end{tabular}


Table 4: Brand Level BSI for Insurance Sector - HL Test and Max-rescaled R Square

\begin{tabular}{|c|c|c|c|c|c|c|}
\hline \multirow{2}{*}{ Brand } & \multicolumn{3}{|c|}{ Hosmer and Lemeshow (HL) } & \multicolumn{3}{|c|}{$\begin{array}{c}\text { Max-rescaled } \\
\text { R-Square }\end{array}$} \\
\hline & $\begin{array}{c}\text { No } \\
\text { Weight }\end{array}$ & $\begin{array}{c}\text { Linear } \\
\text { Weight }\end{array}$ & $\begin{array}{c}\text { Expo } \\
\text { Weight }\end{array}$ & $\begin{array}{c}\text { No } \\
\text { Weight }\end{array}$ & $\begin{array}{c}\text { Linear } \\
\text { Weight }\end{array}$ & $\begin{array}{c}\text { Expo } \\
\text { Weight }\end{array}$ \\
\hline 1 & 0.1018 & 0.2869 & 0.0838 & 0.1281 & 0.1765 & 0.9385 \\
\hline 2 & 0.1560 & 0.7516 & 0.6949 & 0.2063 & 0.2679 & 0.9681 \\
\hline 3 & 0.4469 & 0.1526 & 0.2450 & 0.2238 & 0.2855 & 0.9437 \\
\hline 4 & 0.5875 & 0.8561 & 0.6482 & 0.1301 & 0.1824 & 0.8425 \\
\hline 5 & 0.7373 & 0.5235 & 0.1026 & 0.1654 & 0.2332 & 0.9023 \\
\hline 6 & 0.4178 & 0.6451 & 0.0946 & 0.1370 & 0.1698 & 0.8694 \\
\hline 7 & 0.6221 & 0.5390 & 0.1411 & 0.0424 & 0.0711 & 0.6650 \\
\hline
\end{tabular}

Interpretation:

Percentage Concordant and $\mathrm{C}$ value are In the range of $60 \%-70 \%$. The three techniques (No Weight, Linear Weight and Exponential Weight) seem to have less impact on Percentage Concordant and $C$ values.

Hosmer and Lemeshow Goodness-ofFit test has passed for all the three techniques across all the seven brands $(p>0.05)$.
Max-rescaled R-Square for No Weight and Linear Weight technique is observed to be low $(<0.3)$ across all the brands. However for Exponential Weight method, max-rescaled R-Square value is observed to be high $(0.8-1.0)$. This suggests that Exponential Weight is a better technique amongst the three. It also implies that familiarity is an important driver for brand uniqueness.

\section{Oral Care Sector Brands}

Table 5: Brand Level BSI for Oral Care Sector - Percentage Concordant and C Value

\begin{tabular}{|c|c|c|c|c|c|c|}
\hline Brand & \multicolumn{2}{|c|}{ Percentage Concordant } & \multicolumn{3}{c|}{ C Value } \\
\hline & $\begin{array}{c}\text { No } \\
\text { Weight }\end{array}$ & $\begin{array}{c}\text { Linear } \\
\text { Weight }\end{array}$ & $\begin{array}{c}\text { Expo } \\
\text { Weight }\end{array}$ & $\begin{array}{c}\text { No } \\
\text { Weight }\end{array}$ & $\begin{array}{c}\text { Linear } \\
\text { Weight }\end{array}$ & $\begin{array}{c}\text { Expo } \\
\text { Weight }\end{array}$ \\
\hline 1 & 66.7 & 66.7 & 66.7 & 0.669 & 0.670 & 0.670 \\
\hline 2 & 69.3 & 69.2 & 68.8 & 0.695 & 0.694 & 0.690 \\
\hline 3 & 75.5 & 75.6 & 75.5 & 0.756 & 0.757 & 0.756 \\
\hline 4 & 70.9 & 70.8 & 70.5 & 0.711 & 0.710 & 0.707 \\
\hline 5 & 67.3 & 67.2 & 67.0 & 0.674 & 0.673 & 0.671 \\
\hline 6 & 62.5 & 62.4 & 61.5 & 0.627 & 0.626 & 0.618 \\
\hline
\end{tabular}

${ }^{3}$ Case of multiple regression in which the independent variables are themselves highly correlated 
Table 6: Brand Level BSI for Oral Care Sector - HL Test and Max-rescaled R Square

\begin{tabular}{|c|c|c|c|c|c|c|}
\hline \multirow{2}{*}{ Brand } & \multicolumn{3}{|c|}{ Hosmer and Lemeshow (HL) } & \multicolumn{3}{|c|}{$\begin{array}{c}\text { Max-rescaled } \\
\text { P-Square }\end{array}$} \\
\hline & $\begin{array}{c}\text { No value } \\
\text { Weight }\end{array}$ & $\begin{array}{c}\text { Linear } \\
\text { Weight }\end{array}$ & $\begin{array}{c}\text { Expo } \\
\text { Weight }\end{array}$ & $\begin{array}{c}\text { No } \\
\text { Weight }\end{array}$ & $\begin{array}{c}\text { Linear } \\
\text { Weight }\end{array}$ & $\begin{array}{c}\text { Expo } \\
\text { Weight }\end{array}$ \\
\hline 1 & 0.7352 & 0.1687 & 0.1767 & 0.1347 & 0.1808 & 0.9190 \\
\hline 2 & 0.1233 & 0.3352 & 0.2310 & 0.1730 & 0.2373 & 0.9640 \\
\hline 3 & 0.0651 & 0.1292 & 0.4055 & 0.3043 & 0.3995 & 0.9991 \\
\hline 4 & 0.6411 & 0.7088 & 0.6421 & 0.1956 & 0.2575 & 0.9576 \\
\hline 5 & 0.0666 & 0.0754 & 0.2787 & 0.1380 & 0.2034 & 0.9256 \\
\hline 6 & 0.8162 & 0.3809 & 0.5820 & 0.0717 & 0.1080 & 0.6384 \\
\hline
\end{tabular}

Interpretation:

- Percentage Concordant and $\mathrm{C}$ value are in the range of $60 \%-70 \%$. The three techniques (No Weight, Linear Weight and Exponential Weight) seem to have less impact on Percentage Concordant and $\mathrm{C}$ values.

- Hosmer and Lemeshow Goodness-of-Fit test has passed for all the three techniques across all the six brands ( $p>0.05$ ).

- Max-rescaled R-Square for No Weight and Linear Weight technique is observed to be low $(<0.4)$ across all the brands. However for Exponential Weight method, maxrescaled R-Square value is observed to be high (0.6 - 1.0). This suggests that Exponential Weight is a better technique amongst the three. It also implies that familiarity is an important driver for brand uniqueness.

\section{BRAND LEVEL BSI SCORE COMPUTATION}

\section{Insurance Brands Steps and Outputs}

Step 1: Computation of Brand/Attribute mean

Table 7: Insurance Sector - Brand Level BSI Computation Part 1

\begin{tabular}{|l|l|l|l|l|l|l|l|l|}
\hline Brand & $\begin{array}{c}\text { Familiarity } \\
\text { (Mean) }\end{array}$ & $\begin{array}{c}\text { Unique } \\
\text { (Mean) }\end{array}$ & $\begin{array}{c}\text { VFM } \\
\text { (Mean) }\end{array}$ & $\begin{array}{c}\text { Popularity } \\
\text { (Mean) }\end{array}$ & $\begin{array}{c}\text { Pride } \\
\text { (Mean) }\end{array}$ & $\begin{array}{c}\text { High Quality } \\
\text { (Mean) }\end{array}$ & $\begin{array}{c}\text { Loyalty } \\
\text { (Mean) }\end{array}$ & $\begin{array}{c}\text { Emotion } \\
\text { (Mean) }\end{array}$ \\
\hline 1 & 3.65 & 7.77 & 7.96 & 7.90 & 7.86 & 8.23 & 8.01 & 7.90 \\
\hline 2 & 3.24 & 7.27 & 7.30 & 7.58 & 7.30 & 7.67 & 7.21 & 7.24 \\
\hline 3 & 3.15 & 7.14 & 7.06 & 7.16 & 6.96 & 7.39 & 6.99 & 7.16 \\
\hline 4 & 3.06 & 6.67 & 6.86 & 6.78 & 6.69 & 7.00 & 6.76 & 6.73 \\
\hline 5 & 2.91 & 6.23 & 6.36 & 6.34 & 6.57 & 6.65 & 6.30 & 6.41 \\
\hline 6 & 2.92 & 6.33 & 6.57 & 6.34 & 6.21 & 6.83 & 6.35 & 6.41 \\
\hline 7 & 2.91 & 6.05 & 6.56 & 6.62 & 6.20 & 6.44 & 6.63 & 6.40 \\
\hline
\end{tabular}


Step 2: Parameter Estimates (Exponential Weight on Familiarity Method)

Table 8: Insurance Sector - Brand Level BSI Computation Part 2

\begin{tabular}{|c|c|c|c|c|c|c|c|}
\hline Brand & Intercept & VFM & Popularity & Pride & High Quality & Loyalty & Emotion \\
\hline 1 & -2.74 & 0.00 & 0.28 & 0.09 & 0.22 & -0.04 & -0.13 \\
\hline 2 & -5.59 & 0.10 & -0.06 & 0.30 & 0.13 & 0.19 & 0.07 \\
\hline 3 & -5.22 & 0.17 & 0.00 & 0.18 & 0.12 & 0.03 & 0.21 \\
\hline 4 & -3.20 & 0.16 & 0.09 & 0.08 & 0.07 & 0.10 & 0.04 \\
\hline 5 & -3.16 & 0.10 & 0.18 & -0.12 & 0.07 & 0.08 & 0.16 \\
\hline 6 & -3.42 & 0.21 & 0.11 & -0.03 & 0.08 & 0.13 & 0.02 \\
\hline 7 & -2.73 & 0.00 & -0.06 & 0.03 & 0.11 & 0.08 & 0.18 \\
\hline
\end{tabular}

Step 3: Computation of Log Odds/Probability/BSI Score

Table 9: Insurance Sector - Brand Level BSI Computation Part 3

\begin{tabular}{|c|l|c|c|c|}
\hline Brand & Brand Name & Log Odds & Probability & BSI Score \\
\hline 1 & LIC & 0.60 & 0.65 & 35 \\
\hline 2 & ICICI Prudential & -0.25 & 0.44 & 56 \\
\hline 3 & SBI Life & -0.25 & 0.44 & 56 \\
\hline 4 & HDFC Standard Life & 0.48 & 0.62 & 38 \\
\hline 5 & Bajaj Allianz & -0.19 & 0.45 & 55 \\
\hline 6 & Birla Sunlife & 0.05 & 0.51 & 49 \\
\hline 7 & Max New York Life & -0.43 & 0.39 & 61 \\
\hline
\end{tabular}

Interpretation: As observed from Table 9, LIC and HDFC Standard Life are able to clearly differentiate their unique offerings as perceived by the customers. Other brands have relatively higher BSI scores $(>50)$ indicating service offerings not uniquely positioned in the market.

\section{Oral Care Brands Steps and Outputs}

Step 1: Computation of Brand/Attribute mean

Table 10: Oral Care Sector - Brand Level BSI Computation Part 1

\begin{tabular}{|c|c|c|c|c|c|c|c|c|}
\hline Brand & $\begin{array}{l}\text { Familiarity } \\
(\text { Mean) }\end{array}$ & $\begin{array}{l}\text { Unique } \\
(\text { Mean })\end{array}$ & $\begin{array}{l}\text { VFM } \\
(\text { Mean })\end{array}$ & $\begin{array}{l}\text { Popularity } \\
(\text { Mean) }\end{array}$ & $\begin{array}{l}\text { Pride } \\
(\text { Mean })\end{array}$ & $\begin{array}{c}\text { High Quality } \\
\text { (Mean) }\end{array}$ & $\begin{array}{c}\text { Loyalty } \\
\text { (Mean) }\end{array}$ & $\begin{array}{l}\text { Emotion } \\
\text { (Mean) }\end{array}$ \\
\hline 1 & 3.66 & 7.79 & 7.94 & 7.90 & 7.79 & 8.06 & 7.86 & 7.83 \\
\hline 2 & 3.38 & 7.20 & 7.43 & 7.60 & 7.30 & 7.71 & 7.43 & 7.40 \\
\hline 3 & 3.41 & 7.27 & 7.34 & 7.46 & 7.33 & 7.87 & 7.33 & 7.33 \\
\hline 4 & 3.20 & 6.94 & 7.05 & 7.18 & 7.06 & 7.25 & 6.86 & 6.91 \\
\hline 5 & 2.88 & 6.04 & 6.28 & 6.15 & 5.96 & 6.23 & 6.13 & 6.06 \\
\hline 6 & 2.80 & 5.99 & 6.10 & 6.06 & 5.94 & 6.23 & 6.04 & 5.98 \\
\hline
\end{tabular}


Step 2: Parameter Estimates (Exponential Weight on Familiarity Method)

Table 11: Oral Care Sector - Brand Level BSI Computation Part 2

\begin{tabular}{|c|c|c|c|c|c|c|c|}
\hline Brand & Intercept & VFM & Popularity & Pride & High Quality & Loyalty & Emotion \\
\hline 1 & -2.37 & 0.00 & 0.34 & -0.02 & 0.00 & 0.00 & 0.08 \\
\hline 2 & -6.19 & 0.23 & -0.04 & 0.23 & 0.13 & 0.10 & 0.14 \\
\hline 3 & -8.91 & 0.27 & 0.17 & 0.25 & 0.10 & 0.23 & 0.15 \\
\hline 4 & -3.26 & 0.16 & 0.12 & 0.00 & 0.04 & 0.19 & 0.09 \\
\hline 5 & -3.92 & 0.11 & 0.16 & 0.05 & 0.04 & 0.15 & 0.03 \\
\hline 6 & -1.69 & 0.11 & 0.06 & -0.03 & 0.04 & 0.08 & 0.10 \\
\hline
\end{tabular}

Step 3: Computation of Log Odds/Probability/BSI Score

Table 12: Oral Care Sector - Brand Level BSI Computation Part 3

\begin{tabular}{|c|l|c|c|c|}
\hline Brand & Brand Name & Log Odds & Probability & BSI Score \\
\hline 1 & Colgate & 0.78 & 0.69 & 31 \\
\hline 2 & Close-up & -0.32 & 0.42 & 58 \\
\hline 3 & Pepsodent & -0.25 & 0.44 & 56 \\
\hline 4 & Dabur Red & 1.04 & 0.74 & 26 \\
\hline 5 & Vicco & -0.61 & 0.35 & 65 \\
\hline 6 & Cibaca & 0.47 & 0.62 & 38 \\
\hline
\end{tabular}

Interpretation: As observed from Table 12, Colgate, Dabur Red and Cibaca are able to clearly differentiate their unique offerings as perceived by the customers. Other brands have

\section{SUGGESTIONS}

1. One of the key suggestions is that brand manager or customer segment manager should make sure their brand symmetry index is measured on a continuous basis. This can be achieved by using the model developed through this research. Be it a product or service, the research shows that brands can be measured on their symmetry attribute. The model helps in knowing how similar/dissimilar the brand is with respect to its peers. This can be achieved by measuring customer perception on following eight attributes: relatively higher $\mathrm{BSI}$ scores $(>50)$ Indicating product attributes not uniquely positioned in the market.

- Familiarity

- Unique

- VFM

- Popularity

- Pride

- High Quality

- Loyalty

- Emotion

2. From the research conducted, it was found that LiC and HDFC in Life Insurance segment were able to differentiate their service offerings successfully compared to their competitors. Life Insurance service 
category does suffer from commoditization syndrome. It is quite challenging to differentiate services which are similar. However working on Trust Factor, Product Designs and Customer Connects, the sector can rework on the differentiation themes. Just aggressive marketing will not be sufficient to sell the product in this segment. In fact aggressive sales campaigns may further irritate the potential future customers. Since the customer stays with the brand for longer period (as the policy maturity period is generally between 5-15 years), organizations can use this as an opportunity to connect with customer to communicate the brands unique features so that customers are always in the communication loop. Cross-sell and Upsell opportunities can also be explored during this period.

3. Also from the research conducted, it was found that Colgate, Dabur Red and Cibaca were able to differentiate their service offerings successfully compared to their competitors. Colgate has been pioneer in product innovation in oral care segment. It also successfully positioned its ad 'surakha chakra'. For long there were no active competitors in this segment and Colgate managed to communicate its brand differentiation in the market. Dabur with its ayurvedic and medicinal value proposition was able to differentiate its product offerings. Cibaca with its value for money proposition was able to achieve the differentiation. The segment still has a lot of scope for product innovation to move up in value chain. Liquid wash, brushing at least twice everyday to increase consumption, product ingredients are few areas where the brands can focus on.

4. It is also recommended that brand manager should be working on increasing and maintaining the brand prominence in the minds of their customers; i.e. to enlarge and strengthen the span of the network related to the brand in customer's memory. This strategy focuses on the number of attributes customer links with the brand rather than specific attributes being linked to the brand. It is the 'Quantity' not the 'Quality' which matters here. This gives multiple options to the communication team in designing the message being sent to customers thus providing opportunities for innovation and entertainment.

5. There are various inferences from the study. First inference is the finding that challenges the practice of conducting research in the area of attribute studies to identify and suggest the best positioning strategy in the market. It is quite difficult to accept the proposition that claims one particular position is better than the other as the attribute positioning itself does not translate into improving loyalty or profitability levels. The second inference also questions the idea behind monitoring few key attributes (through line/bar charts) and including them as key performance metrics. Generally such a metric is based on the hypothesis that some attributes are more important than others in driving customer purchase decision and loyalty. The result of this study does not support this assumption. Alternatively all the brand attributes can be monitored on a regular basis for a better evaluation of brand performance. 
6. It should not be deduced from the results of this study that the best positioning on an attribute based perceptual map is at the center of the grid. Though it is advantageous to associate the brand with as many attributes as possible, this may not again yield a central position. It is recommended that having a particular distinct location on the perceptual map is important, which may be any positive location on the tool. A distinct location does not necessarily translate into significantly high brand loyalty by the customers. There are, nevertheless, other advantages of being unique which have not been covered in this study. Being unique, however, can assist in marketing communications and provide customers a method through which they can effortlessly classify and consider the brand. This would make marketing communications more effective in obtaining the results.

7. The researcher also suggests a two stage strategy approach for managing and building brands: short term and long term. Short term strategy needs to focus on identifying particular attributes that needs to be communicated in the marketplace. A particular attribute can be focused on in the short term identifying the message that can provide the best creative implementation. The objective here is developing advertisements which would be liked by the customers so that message communication can be achieved. An important point to note here is that even if the manager decides to take those attributes that have strongest association with loyalty, they would most likely be the same set of attributes that even the competition would be considering for positioning the brand. This makes the marketing communication activity even more challenging to ensure that the brand is distinctly and prominently placed. Once done, it would make very easy for the customer to understand what is being advertized and who is advertising (i.e. effective processing of information in customer's memory). In long term, the goal would be to construct a pool of perceptions about the brand in the customers mind. This gradual accumulation of attributes would build-up the customer's 'share of mind' which would lead to:

- easier brand recall

- creation of barriers for competitors in customer's 'share of mind'

\section{CONCLUSION}

It is quite evident that brand perceptions are of significant importance to brand managers and advertisers. The brand that can manage this key input to their advantage would end up being successful. Measuring the Brand Symmetry should be the first step towards understanding the brand and its perception in minds of the customer. The research model (brand symmetry index score) helps the brand manager to achieve that. With focus on eight attributes and using an algorithm to compute a symmetry score, it is now possible to monitor the performance of brand positioning and differentiation on a regular basis.

Organizations have two choices on product strategy: Differentiation strategy or Low cost strategy. Organization in different point in time and situation may pursue different strategies. If the organization decides to pursue differentiation strategy then brand symmetry 
must be fought by advertising. As suggested by the current study, developing loyalty by working on other brand attributes may be waste of resources if brand symmetry is not controlled. Organization must work on developing unique brand attributes and make customers believe that all brand choices are not the same and there is a difference (brand 'LIC' communication on volume and value of settlements). In any case, advertising will be needed to create brand differentiation for fighting brand symmetry before creating brand loyalty.

Organization following low cost strategy would like its advertising to focus on creating high brand symmetry thereby sensitizing customers towards price elasticity. The usual advertising line "why pay more when you can get the same for less" actually fosters brand symmetry perception among the customers (brand 'Cibaca' communication on Value for Money). This way the brand loyalty of competitor brands is challenged and the customers are lured towards products with similar attributes but with lower price. Instead of fighting brand symmetry, the organization actually wants to create brand symmetry through advertising to adopt low price strategy for its brand.

Off course, the multi-attribute metric being employed in this study is a basic one which reflects the aggregated belief a customer has towards the brand. Hence it is the power of the customer's attitude and familiarity towards a brand that drives the future behaviour and action. There is an opportunity here to further extend the research to differentiate clearly between 'attitudinal' and 'share of mind' concept to further justify the results presented. More testing is required to confirm if the relationship is impacted by 'brands share of mind' or 'customers attitude towards the brand' or a combination of two concepts to further improve the understanding on how customer perceptions drive future behaviour.

It is worth mentioning that the results obtained in this study complement the academic research that revealed a systematic weakness in the correlation of particular attributes with particular brands (Riley et al 1997). The systematic weakness is being judged at individual level which tries to review the ability of a particular attribute/brand association being vital in the future purchase decisioning. These outcomes does support organizations activities for duing market research into brand perception/image as it is essential to know what customers think about the brand. The findings however suggest that customer's perception about the brand is less important at any specific instance as long as the overall brand perception is positive. The brand managers should not be apprehensive about customer's perception that the brand is offering value for money, quality service or expertise. Customers familiarity of the brand is more vital and the more the customer knows about the brand, the better it is.

\section{BIBLIOGRAPHY}

Aaker, D. A. (1991), 'Managing brand equity: Capitalizing on the value of a brand name', The Free Press, New York.

Aaker, D. A. and Shansby, G. (1982), 'Positioning your product', Business Horizons, Vol. 25, pp. 56-62.

Aaker, D. and Myers, J. G. (1987), 'Advertising management', 3rd edn, Prentice-Hall, New Jersey. Aaker, David A (1996), 'Measuring Brand Equity Across Products and Markets,' California Management Review, 38 (2), 102-120.

Aaker, David. (2003), 'The Power of the Branded Differentiator', MIT Sloan Management Review, Vol. 45 Issue 1, p83-87 
Aaker, J. L. (1997), 'Dimensions of brand personality', Journal of Marketing Research, Vol. 34, August, pp. 347-356.

An Tien Hsieh and Wen Ting Chang (2004), 'The Effect of Consumer Participation on Price Sensitivity', Journal of Consumer Affairs, Vol. 38 Issue 2, p282-296

Baidya, Mehir; Maity, Bipasha. (2011), 'Relationship between Marketing Efforts and Sales of Consumer Brands: An Empirical Study in India', International Journal of Management; Part 2, Vol. 28 Issue 1, p387-393

Baldinger, Alan L, and Joel Rubinson (1996), 'Brand Loyalty: The Link Between Attitude and Behavior', Journal of Advertising Research, 36 (6), 22-34.

Bello, David c., and Morris Holbrook (1995), 'Does an Absence of Brand Equity Generalize Across Product Classes?', Journal of Business Research, 34, 125-131.

Bennett, Rebekah and Rundle-Thiele, Sharyn (2005), 'The brand loyalty life cycle: Implications for marketers', Journal of Brand Management, Vol. 12 Issue 4, p250-263

Bhimrao Ghodeswar, M. (2008), 'Building brand identity in competitive markets: a conceptual model', Journal of Product \& Brand Management; Vol. 17 Issue 1, p4-12

Bird, M., Channon, and Ehrenberg, A. S. (1970), 'Brand image and brand usage', Journal of Marketing Research, Vol. 7, August, pp. 307-314.

Chaudhuri, A. (1995), 'Brand equity or double jeopardy', Journal of Product \& Brand Management, Vol. 4, No. 1, pp. 26-32.

Chaudhuri, Arjun (1998), 'Product Class Effects on Brand Loyalty,' Journal of Marketing Management, 8(2), 66-75.

Chaudhuri, Arjun (2002), 'How Brand Reputation Affects the Advertising-Brand Equity Link', Journal of Advertising Research,Vol. 42 Issue 3, p33-43

Chernev, Alex and Carmon, Ziv (1996), 'New Perspectives on Brand Differentiation', Advances in Consumer Research, Vol. 23 Issue 1, p394-394

Davidson, Hugh (1976), 'Why Most New Consumer Brands Fail', Harvard Business Review,
Mar-Apr., 127-132

Delgado-Ballester, E. and Munuera-Alema'n, J. L. (2001), 'Brand trust in the context of consumer loyalty', European Journal of Marketing, Vol. 35, Nos 11/12, pp. 1238-1258.

Dwivedi, Abhishek; Merrilees, Bill; Sweeney, Arthur. (2010), 'Brand extension feedback effects: A holistic framework', Journal of Brand Management; Vol. 17 Issue 5, p328-342, 15p

Etter, Bill (2005), 'Loyalty Leverage', Marketing Research, Vol. 17 Issue 3, p31-36

Harter, John F. R. (2004), 'How Brand Loyalty Affects Product Differentiation', Journal of Applied Economics \& Policy, Vol. 23, p1-13

Heath, Robert; Brandt, David; Nairn, Agnes (2006), 'Brand Relationships: Strengthened by Emotion, Weakened by Attention', Journal of Advertising Research, Vol. 46 Issue 4, p410-419

Hsiu-Yuan Tsao and Li-Wei Chen (2005), 'Exploring Brand Loyalty from the Perspective of Brand Switching Costs', International Journal of Management, Vol. 22, No. 3

lyer, Rajesh; Muncy, James A (2005), 'The Role of Brand Parity in Developing Loyal Customers', Journal of Advertising Research, Vol. 45 Issue 2, p222-228

Iyer, Shobha G; Banerjee, Bibek; Garber, Lawrence L. (2011), 'Determinants of Consumer Attitudes toward Brand Extensions: An Experimental Study', International Journal of Management; Part 2, Vol. 28 Issue 3, p809-823

Jacoby, Jacob (1971), 'A Model of Multi-Brand Loyalty,' Journal of Advertising Research, 11 (3),25-31.

Jacoby, Jacob, and Robert Chestnut (1978), 'Brand Loyalty Measurement and Management', New York, NY: John Wiley.Johnson, M. and Garbarino, E. (1999), 'The different roles of satisfaction, trust and commitment in customer relationships', Journal of Marketing, pp. 70-87.

Joyce, T., (1963), 'Techniques of brand image measurement', New Developments in Research, Market Research Society, London, pp. 45-63.

Keiningham, Timothy L., Aksoy, Lerzan, PerkinsMunn Tiffany, and Vavra Terry G. (2005), 'The 
brand-customer connection', Marketing Management, Vol. 14 Issue 4, p33-37

Keller, K. (1993), 'Conceptualizing, measuring, and managing customer-based brand equity', Journal of Marketing, Vol. 57, January, pp. 1-22.

Keller, K. L. (2003), 'Brand synthesis: The multidimensionality of brand knowledge', Journal of Consumer Research, Vol. 29, March, pp. 595-601.

Kerin, Roger. A\&P. Varadarajan, Rajan and Robert A. Peterson (1992), 'First Mover Advantage: A Synthesis, Conceptual Framework and Research Propositions', Journal of Marketing, Oct., 3352Kutcher, Kevin (2005), 'Advertising your unique selling proposition', Rural Telecommunications, Vol. 24 Issue 3, p36-40

Levitt, Theodore (1980), 'Marketing Success Through Differentiation of Anything', Harvard Business Review, Jan-Feb., 83-92

Lockwood, Lisa (2005),'Powering Brands With Emotion', Women's Wear Daily, Vol. 190 Issue 107, Special Section p24-24

Neely, A. and Ranaweera, C. (2001), 'The link between service quality and customer retention', European Operations Management Association 8th Annual Conference, Bath, pp. 1199-211.

Prabhu , J. and Ranaweera, C (2003), 'The influence of satisfaction and trust and switching barriers on customer retention in a continuous purchasing setting', International Journal of Service Industry Measurement, Vol. 14, pp. 374395.

Punniyamoorthy, M.; Raj, M. Prasanna Mohan. (2007), 'An empirical model for brand loyalty measurement', Journal of Targeting, Measurement \& Analysis for Marketing; Vol. 15 Issue 4, p222-233

Raj, S. P. (1985), 'Striking a Balance between Brand 'Popularity' and Brand Loyalty', Journal of Marketing, Vol. 49 Issue 1, p53-59
Ramaseshan, B and Hsiu-Yuan Tsao (2007), 'Moderating effects of the brand concept on the relationship between brand personality and perceived quality', Journal of Brand Management,Vol. 14 Issue 6, p458-466

Ries and Trout (1981), 'Positioning the battle for your mind', McGraw-Hill Inc, New York.Roland Rust, Valarie A.Zeithaml, and Katherine N. Lemon (2004), 'Customer-Centered Brand Management', Harvard Business Review, Vol. 82 Issue 12, p144144

Romaniuk, Jenni and Bogomolova, Svetlana (2005), 'Variation in brand trust scores', Journal of Targeting, Measurement and Analysis for Marketing, Vol. 13, 4, 363-373

Romaniuk, Jenni; Sharp, Byron (2003), 'Measuring brand perceptions: Testing quantity and quality', Journal of Targeting, Measurement \& Analysis for Marketing, Vol. 11 Issue 3, p218

Sagar, Mahim; Singh, Deepali; and Agrawal, D. P. (2006), 'Framework of Ethical Brand Positioning', Journal of Management Research, Vol. 6 Issue 2, p72-83

Schmalensee, Richard (1982), 'Product Differentiation Advantages of Pioneering Brands', American Economic Review, Vol. 72 Issue 3, p349

Semon, Thomas T. (1993), 'Consider brand loyalty and response styles in customer satisfaction research', Marketing News,Vol. 27 Issue 22, p9

Shansby, G. and Aaker, D. (1982), 'Positioning your product', Business Horizons, Vol. 25, pp. 56-62.

Thamaraiselvan, $N$ and Raja (2008), 'How do consumers evaluate brand extensions-research findings from India', J. Journal of Services Research; Vol. 8 Issue 1, p43-62

Thomas, Bejoy John and Sekar, P. C. (2008), 'Measurement and Validity of Jennifer Aaker's Brand Personality Scale for Colgate Brand', Vikalpa: The Journal for Decision Makers; Vol. 33 Issue 3, p49-61 